\title{
SOME RECENT ADVANCES IN THE ORGANOMETALLIC CHEMISTRY OF THALLIUM(III)
}

\author{
R. OKAWARA \\ Department of Applied Chemistry, Osaka University. \\ Yamadakami, Suita, Osaka, Japan
}

\begin{abstract}
A summary, dealing mainly with the authors own work, of the preparations, reactions and structures of monoalkylthallium, alkylcyanothallium and unsymmetrical diorganothallium derivatives. is presented.
\end{abstract}

\section{INTRODUCTION}

Our review ${ }^{1}$ 'Recent Advances in Organothallium Chemistry' included a list of 452 organothallium(III) and 26 thallium(I) organic derivatives which had been reported by the end of 1969 . Other short reviews ${ }^{2,3}$ have also been published.

Several triorganothalliums, $\mathbf{R}_{3} T 1$, have been prepared since 1930 . They all are hydrolysed readily by atmospheric moisture, and some of them are inflammable in air. It is frequently observed that one of the three organic groups of triorganothalliums is easily substituted with more electronegative groups, giving stable diorganothallium derivatives. Another notable feature of trialkylthalliums is that, although they are monomeric in solution, intermolecular alkyl exchange reactions occur easily.

Since the preparation of diethylthallium compounds in 1870, a large variety of diorganothallium compounds of the type $R_{2} T I X$ have been synthesized and these are known to be among the most stable organometallic compounds. Most compounds of this type are thought to be salts of the diorganothallium cation which is isoelectronic with diorganomercurials, $\mathrm{R}_{2} \mathrm{Hg}$. It has been believed that the alkyl exchange reaction, which is often observed in trialkylthalliums, is difficult to occur in dialkylthallium compounds, because of the particular stability of the C-Tl-C group. We found that in some methylethylthallium derivatives, $\mathrm{CH}_{3}\left(\mathrm{C}_{2} \mathrm{H}_{5}\right) \mathrm{TlX}$, the exchange of the alkyl groups occurred under mild conditions to form redistribution products. Other interesting reactions found for RR'TIX are alkyl replacement and dealkylation reactions.

We isolated several novel monomethylthallium dicarboxylates for the first time in 1967 from the reaction of dimethylthallium carboxylate with mercuric dicarboxylate. We have also developed a convenient method for the preparation of monoalkylthallium derivatives from aqueous thallic acetate using some mild alkylating reagents, in the absence of chloride; 
bromide or iodide anions. They are air stable but decompose slowly at room temperature.

In this lecture, the preparation, properties and some interesting reactions of monoalkylthallium and unsymmetrical diorganothallium derivatives will be described together with structural considerations by means of i.r. and ${ }^{1} \mathrm{H}$ n.m.r.

\section{MONOALKYLTHALLIUM DERIVATIVES}

Monoaryl- and monovinylthallium derivatives can be prepared by the reactions of thallic salts with corresponding organo-derivatives of boron ${ }^{4-7}$, mercury ${ }^{8-13}$ and $\operatorname{tin}^{14}$.

$$
\begin{gathered}
\mathrm{R}_{\mathrm{n}} \mathrm{M}+\mathrm{TlY}_{3} \rightarrow \mathrm{RTIY}_{2}(\mathrm{R}=\text { aryl or vinyl } ; \mathrm{M}=\mathrm{B}, \mathrm{Hg} \text { or } \mathrm{Sn} ; \mathrm{Y}=\mathrm{Cl}, \\
\left.\mathrm{Br} \text { or } \mathrm{OCOR}^{\prime}\right) \\
\mathrm{R}_{2} \mathrm{TlX}+\mathrm{TlX}_{3} \rightarrow 2 \mathrm{RTIX}_{2}(\mathrm{R}=\text { aryl or vinyl } ; \mathrm{X}=\mathrm{Cl} \text { or } \mathrm{Br})
\end{gathered}
$$

On the other hand, the history of preparation of lower monoalkyl compounds was not straightforward. Melnikov and Gratscheva reported ${ }^{15}$ that they first succeeded in preparing several monoalkylthallium dihalides, $\mathrm{RTIX}_{2}\left(\mathrm{R}=\mathrm{CH}_{3}, \mathrm{C}_{2} \mathrm{H}_{5}\right.$ and i- $\left.\mathrm{C}_{5} \mathrm{H}_{11}\right)$. However, Sarrach ${ }^{16}$ as well as Hart and Ingold ${ }^{17}$ failed to confirm the results and suggested non-existence or instability of these compounds by carrying out some skillful experiments. We examined a reaction of $\left(\mathrm{CH}_{3}\right)_{2} \mathrm{TlOAc}$ with $\mathrm{Tl}(\mathrm{OAc})_{3}$ in water or in methanol, and found that the reaction did not occur at room temperature. At elevated temperature TlOAc and $\mathrm{CH}_{3} \mathrm{OAc}$ were obtained. These seem to be the decomposition products of the expected compound, $\mathrm{CH}_{3} \mathrm{Tl}(\mathrm{OAc})_{2}$.

We have found ${ }^{18}$ the existence of the monomethylthallium species in considerable duration at room temperature by the analysis* of ${ }^{1} \mathrm{H}$ n.m.r. spectra of the reaction system (1) (where $R=\mathrm{R}^{\prime}=\mathrm{CH}_{3}$ ).

$$
\mathrm{R}_{2} \mathrm{TlOCOR}^{\prime}+\mathrm{Hg}\left(\mathrm{OCOR}^{\prime}\right)_{2} \rightarrow \mathrm{RTl}\left(\mathrm{OCOR}^{\prime}\right)_{2}+\mathrm{RHgOCOR}^{\prime}
$$

\section{Preparation and properties}

(i) Alkylthallium dicarboxylates

According to the reaction (1) in methanol, the following compounds have been isolated :

$$
\begin{aligned}
& \mathrm{CH}_{3} \mathrm{Tl}\left(\mathrm{OCOCH}_{3}\right)_{2}{ }^{21,22} \text {, m.p. } 102-103^{\circ} \mathrm{C} \text {; } \\
& \mathrm{CH}_{3} \mathrm{Tl}\left(\mathrm{OCOC}_{3} \mathrm{H}_{7}-\mathrm{i}\right)_{2}{ }^{22} \text {, m.p. } 130-131^{\circ} \mathrm{C} \text {; } \\
& \mathrm{C}_{2} \mathrm{H}_{5} \mathrm{Tl}\left(\mathrm{OCOC}_{3} \mathrm{H}_{7}-1\right)_{2}{ }_{2}^{22} \text {, m.p. } 121-122^{\circ} \mathrm{C} \text {; }
\end{aligned}
$$

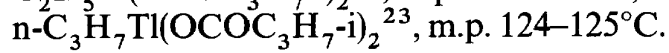

These monoalkylthallium dicarboxylates slowly decompose in aqueous solution even at room temperature according to the following scheme $\mathrm{e}^{22,24}$.

$$
\begin{array}{r}
\mathrm{RTl}\left(\mathrm{OCOR}^{\prime}\right)_{2} \stackrel{\mathrm{H}_{2} \mathrm{O}}{\longrightarrow} \mathrm{R}^{\prime} \mathrm{COOR}+\mathrm{ROH}+\mathrm{R}^{\prime} \mathrm{COOH}+\mathrm{TlOCOR}^{\prime} \\
\left(\mathrm{R}=\mathrm{CH}_{3}, \mathrm{R}^{\prime}=\mathrm{CH}_{3} \text { or i- } \mathrm{C}_{3} \mathrm{H}_{7} ; \mathrm{R}=\mathrm{C}_{2} \mathrm{H}_{5}, \mathrm{R}^{\prime}=\mathrm{i}-\mathrm{C}_{3} \mathrm{H}_{7}\right)
\end{array}
$$

* The ratio of $J\left(\mathrm{~T} 1-\mathrm{CH}_{3}\right)$ for the monomethylthallium species to that for the dimethylthallium cation is almost similar to $J\left(\mathrm{RTI}^{2+}\right): J\left(\mathrm{R}_{2} \mathrm{Tl}^{+}\right)$observed for the vinyl and aromatic series $^{19,20}$. 
The decomposition reaction of methylthallium diacetate occurs immediately in aqueous sodium halide solutions as indicated below.

$$
\mathrm{CH}_{3} \mathrm{Tl}\left(\mathrm{OCOCH}_{3}\right)_{2} \frac{\mathrm{NaX}}{\mathrm{H}_{2} \mathrm{O}}-\mathrm{TlX}+\mathrm{CH}_{3} \mathrm{X}+2 \mathrm{NaOCOCH}_{3}(\mathrm{X}=\mathrm{Cl}, \mathrm{Br} \text { or I })
$$

The amount of precipitated thallous halide was almost quantitative, and the methyl halide was detected as the gaseous product ${ }^{22}$.

Another interesting property of these compounds is their strong tendency to form stable diorganothallium compounds by the reactions with mild alkylating reagents. The reaction of monomethylthallium dicarboxylates with tetramethyltin gave $\left(\mathrm{CH}_{3}\right)_{2}$ TlOCOR' and that with $\mathrm{NaB}\left(\mathrm{C}_{6} \mathrm{H}_{5}\right)_{4}$ gave a phenylated product, $\mathrm{CH}_{3}\left(\mathrm{C}_{6} \mathrm{H}_{5}\right) \mathrm{Tl}\left[\mathrm{B}\left(\mathrm{C}_{6} \mathrm{H}_{5}\right)_{4}\right]$. The formation of a fairly stable $\mathrm{CH}_{3}(\mathrm{CN}) \mathrm{TlOAc}$ in the reaction of $\mathrm{CH}_{3} \mathrm{Tl}(\mathrm{OAc})_{2}$ with $\left(\mathrm{CH}_{3}\right)_{3} \mathrm{SnCN}^{25}$, in chloroform, may also be associated with this tendency.

\section{(ii) Alkylcyanothallium carboxylates}

We have found that the monomethylthallium species was produced in fairly good yield in the early stage of the alkylation reaction of $\mathrm{Tl}(\mathrm{OAc})_{3}$. The yield of dimethylthallium cation increased with time or when the mole ratio of $\mathrm{CH}_{3}: \mathrm{Tl}$ employed was greater than unity, as shown ${ }^{26}$ in Table 1. These facts suggest that the methylation of thallium proceeds in two steps.

Table 1. Methylation of thallic acetate with some methyltin compounds

\begin{tabular}{|c|c|c|c|c|c|c|}
\hline \multirow{3}{*}{$\begin{array}{l}\text { Methyltin } \\
\text { Compound }\end{array}$} & \multirow{3}{*}{$\begin{array}{l}\text { Mole } \\
\text { ratio } \\
\text { (Sn:Tl) }\end{array}$} & \multirow{3}{*}{ Solvent } & \multicolumn{4}{|c|}{ Product $(\%)$ afrer } \\
\hline & & & \multicolumn{2}{|c|}{$3 \mathrm{~h}$} & \multicolumn{2}{|c|}{$24 \mathrm{~h}$} \\
\hline & & & $\mathrm{CH}_{3} \mathrm{Tl}^{2+}$ & $\left(\mathrm{CH}_{3}\right)_{2} \mathrm{Tl}^{+}$ & $\mathrm{CH}_{3} \mathrm{Tl}^{2+}$ & $\left(\mathrm{CH}_{3}\right)_{2} \mathrm{Tl}^{+}$ \\
\hline \multirow[t]{2}{*}{$\left(\mathrm{CH}_{3}\right)_{4} \mathrm{Sn}$} & 1 & $\mathrm{CH}_{3} \mathrm{OH}$ & 70 & 28 & 26 & 62 \\
\hline & $1 / 4$ & $\mathrm{CH}_{3} \mathrm{OH}$ & 59 & 0 & & \\
\hline \multirow[t]{3}{*}{$\left(\mathrm{CH}_{3}\right)_{3} \mathrm{SnOAc}$} & 1 & $\mathrm{CH}_{3} \mathrm{OH}$ & 78 & 8 & 44 & 52 \\
\hline & $1 *$ & $\mathrm{CH}_{3} \mathrm{OH}$ & - & - & 57 & 9 \\
\hline & $1 / 3$ & $\mathrm{CH}_{3} \mathrm{OH}$ & 61 & 0 & & \\
\hline \multirow[t]{2}{*}{$\left(\mathrm{CH}_{3}\right)_{2} \mathrm{SnF}_{2}$} & 1 & $\mathrm{H}_{2} \mathrm{O}$ & 56 & 8 & $0 \dagger$ & $20 \dagger$ \\
\hline & $1 / 2$ & $\mathrm{H}_{2} \mathrm{O}$ & 43 & 0 & & \\
\hline
\end{tabular}

* In the presence of $\mathrm{NaCN}$ (mole ratio. $\mathrm{Tl}: \mathrm{CN}=1$ ).

+ Monomethylthallium species seems to decompose to $\mathrm{CH}_{3} \mathrm{OH}$ and $\mathrm{CH}_{3} \mathrm{COOCH}_{3}$.

However, in the presence of $\mathrm{NaCN}$ further methylation of the monomethylthallium species is retarded. This is probably a consequence of the formation of the stable $\mathrm{C}-\mathrm{Tl}-\mathrm{C}$ configuration ${ }^{25,27}$ in $\mathrm{CH}_{3}(\mathrm{CN})$ TIOAc.

Methylation of $\mathrm{Tl}(\mathrm{OAc})_{3}$ to form $\mathrm{CH}_{3}(\mathrm{CN}) \mathrm{TlOAc}$ was also observed with ammonium methylpentafluorosilicate ${ }^{28}$ in the presence of NaCN. Similarly the preparation of ethylcyanothallium acetate with tetraethyltin in methanol has been carried out ${ }^{26}$.

Alkylcyanothallium acetates are thermally stable and useful starting materials for the alkylthallium derivatives. Alkylcyanothallium acetate, $\mathrm{R}(\mathrm{CN}) \mathrm{TlOAc}\left(\mathrm{R}=\mathrm{CH}_{3}, \mathrm{C}_{2} \mathrm{H}_{5}\right)$, can be converted into $\mathrm{RTIY}_{2}(\mathrm{Y}=\mathrm{N}, \mathrm{N}$ dialkyldithiocarbamate ${ }^{29}$, oxinate or tropolonate) by the reaction with 
R. OKAWARA

excess $\mathrm{KSSCNR}_{2}$, oxine or tropolone. However, with an equivalent amount of oxine or tropolone, $\mathrm{R}(\mathrm{CN}) \mathrm{TlY}^{30}$ was the product.

\section{UNSYMMETRICAL DIORGANOTHALLIUM DERIVATIVES}

Unsymmetrical diarylthallium compounds, $\left(p-\mathrm{CH}_{3} \mathrm{C}_{6} \mathrm{H}_{4}\right)\left(\mathrm{C}_{6} \mathrm{H}_{5}\right) \mathrm{TlX} \mathrm{X}^{5,31}$ have been reported, but the attempts ${ }^{5}$ to obtain unsymmetrical dialkylthallium derivatives were unsuccessful. We succeeded in preparing these novel unsymmetrical compounds ${ }^{25,32}$ through the reactions of monoalkylthallium compounds with appropriate organometallic reagents, as shown below.

$$
\begin{aligned}
\mathrm{RTIY}_{2}+\left(\mathrm{CH}_{3}\right)_{4} \mathrm{Sn} & \rightarrow \mathrm{CH}_{3} \mathrm{RTIY}+\left(\mathrm{CH}_{3}\right)_{3} \mathrm{SnY} \\
\mathrm{RTIY}_{2}+\mathrm{R}^{\prime} \mathrm{B}(\mathrm{OH})_{2} & \rightarrow \mathrm{RR}^{\prime} \mathrm{TlY}\left(\mathrm{R}=\mathrm{CH}_{3}, \mathrm{C}_{2} \mathrm{H}_{5}, \mathrm{n}-\mathrm{C}_{3} \mathrm{H}_{7} \text { and } \mathrm{C}_{6} \mathrm{H}_{5} ;\right. \\
& \left.\mathrm{R}^{\prime}=\mathrm{C}_{6} \mathrm{H}_{5} \text { and } p-\mathrm{CH}_{3} \mathrm{C}_{6} \mathrm{H}_{4} ; \mathrm{Y}=\mathrm{OCOC}_{3} \mathrm{H}_{7}-\mathrm{i}\right)
\end{aligned}
$$

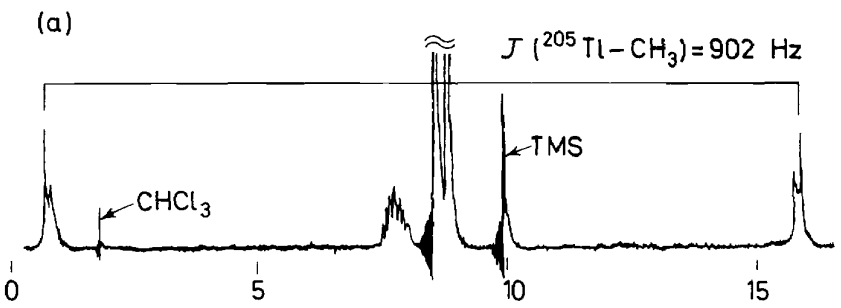

(b)

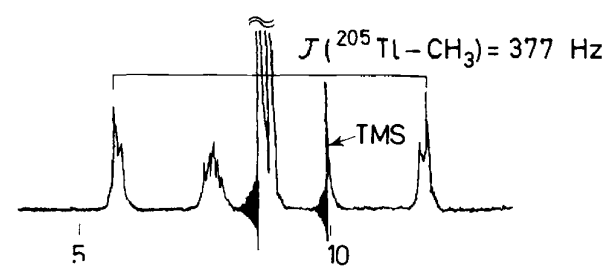

(c)

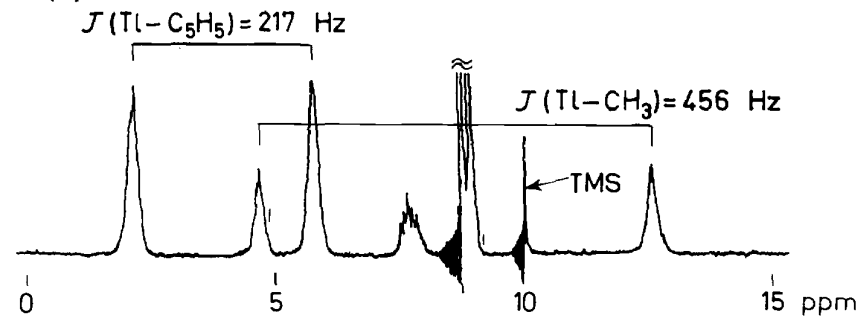

Figure 1. ${ }^{1} \mathrm{H}$ n.m.r. spectra in $\mathrm{CDCl}_{3}$ at $60 \mathrm{MHz}$ and $20^{\circ} \mathrm{C}$.

(a) $\mathrm{CH}_{3} \mathrm{Tl}\left(\mathrm{OCOC}_{3} \mathrm{H}_{7} \text {-i }\right)_{2}$

(b) $\left(\mathrm{CH}_{3}\right)_{2} \mathrm{TIOCOC}_{3} \mathrm{H}_{7}-\mathrm{i}$

(c) $\mathrm{CH}_{3}\left(\mathrm{C}_{5} \mathrm{H}_{5}\right) \mathrm{TlOCOC} \mathrm{H}_{7}-\mathrm{i}\left(J\left({ }^{205} \mathrm{~T}\right]-\mathrm{CH}_{3}\right)$ and $\left.J\left({ }^{203} \mathrm{~T}\right]-\mathrm{CH}_{3}\right)$ were not resolved.) 
Other less common methods of preparation are as follows.

$\mathrm{CH}_{3}(\mathrm{CN}) \mathrm{TlOCOCH} \mathrm{C}_{3}+\left(\mathrm{n}-\mathrm{C}_{4} \mathrm{H}_{9}\right)_{3} \mathrm{Sn}\left(\mathrm{CH}_{2} \mathrm{CH}=\mathrm{CH}_{2}\right)$

$$
\rightarrow \mathrm{CH}_{3}\left(\mathrm{H}_{2} \mathrm{C}=\mathrm{CHCH}_{2}\right) \mathrm{TlOCOCH}{ }_{3}+\left(\mathrm{n}_{-} \mathrm{C}_{4} \mathrm{H}_{9}\right)_{3} \mathrm{SnCN}^{33}
$$

$\mathrm{CH}_{3} \mathrm{Tl}\left(\mathrm{OCOC}_{3} \mathrm{H}_{7}-\mathrm{i}\right)_{2}+\left(\mathrm{n}-\mathrm{C}_{4} \mathrm{H}_{9}\right)_{3} \mathrm{SnCl}+\mathrm{C}_{5} \mathrm{H}_{5} \mathrm{Tl} \rightarrow$

$\mathrm{CH}_{3}\left(\mathrm{C}_{5} \mathrm{H}_{5}\right) \mathrm{TlOCOC}_{3} \mathrm{H}_{7}-\mathrm{i}+\left(\mathrm{n}_{-} \mathrm{C}_{4} \mathrm{H}_{9}\right)_{3} \mathrm{SnOCOC}_{3} \mathrm{H}_{7}-\mathrm{i}+\mathrm{TlCl}^{34}$

$2 \mathrm{CH}_{3} \mathrm{TlO}+2 \mathrm{C}_{6} \mathrm{H}_{5} \mathrm{C} \equiv \mathrm{CH} \stackrel{\mathrm{CO}_{2}}{\longrightarrow}\left[\mathrm{CH}_{3}\left(\mathrm{C}_{6} \mathrm{H}_{5} \mathrm{C} \equiv \mathrm{C}\right) \mathrm{Tl}\right]_{2} \mathrm{CO}_{3}$

$\left[\mathrm{CH}_{3}\left(\mathrm{C}_{6} \mathrm{H}_{5} \mathrm{C} \equiv \mathrm{C}\right) \mathrm{Tl}\right]_{2} \mathrm{CO}_{3}+2 \mathrm{Y}^{-} \rightarrow 2 \mathrm{CH}_{3}\left(\mathrm{C}_{6} \mathrm{H}_{5} \mathrm{C} \equiv \mathrm{C}\right) \mathrm{TlY}{ }^{25}$

$\left(\mathrm{Y}=\mathrm{Cl}\right.$, OAc or $\left.\mathrm{B}\left(\mathrm{C}_{6} \mathrm{H}_{5}\right)_{4}\right)$

$\mathrm{CH}_{3}(\mathrm{CN}) \mathrm{TlOCOCH}{ }_{3}+\mathrm{NaB}\left(\mathrm{C}_{6} \mathrm{H}_{5}\right)_{4} \rightarrow\left[\mathrm{CH}_{3}\left(\mathrm{C}_{6} \mathrm{H}_{5}\right) \mathrm{Tl}\right] \mathrm{B}\left(\mathrm{C}_{6} \mathrm{H}_{5}\right)_{4}{ }^{25}$

The ${ }^{1} \mathrm{H}$ n.m.r. spectra of representative methylthallium compounds are shown in Figure 1. The indirect spin-spin coupling constants between the methyl protons and the thallium nuclei for these unsymmetrical diorganothallium carboxylates, together with those of monomethylthallium carboxylates are shown in Table 3 . The $\left.J(\mathrm{~T}]-\mathrm{CH}_{3}\right)$ value increases with increasing electronegativity of $\mathbf{R}$.

\section{Reactions}

(i) Redistribution ${ }^{35}$

Methylethylthallium thiomethoxide and thiophenoxide were tound to redistribute easily to dimethyl- and diethylthallium derivatives, in chloroform or benzene solution, even at room temperature. On the other hand, the oxinate, isobutylate and tropolonate, in which the ligands are bonded to thallium through oxygen and/or nitrogen, do not show any appreciable

Table 2. Redistribution reaction in refluxing toluene for $5 \mathrm{~h}$ $\left(\mathrm{CH}_{3}\right)_{2} \mathrm{TlX}+\left(\mathrm{C}_{2} \mathrm{H}_{5}\right)_{2} \mathrm{TlX} \rightarrow 2 \mathrm{CH}_{3}\left(\mathrm{C}_{2} \mathrm{H}_{5}\right) \mathrm{TlX}$

\begin{tabular}{lcc}
\hline \multicolumn{1}{c}{$\mathrm{X}$} & $\begin{array}{c}\text { Initial concn. of } \\
\left(\mathrm{CH}_{3}\right)_{2} \mathrm{TlX}(\mathrm{M})^{*}\end{array}$ & $\begin{array}{c}\text { Conversion } \\
(\%)\end{array}$ \\
\hline $\mathrm{SCH}_{3}$ & 0.053 & 53 \\
$\mathrm{SC}_{6} \mathrm{H}_{5}$ & 0.038 & 48 \\
$\mathrm{SSCN}\left(\mathrm{CH}_{3}\right)_{2}$ & 0.026 & 0 \\
Oxinate & 0.025 & 47 \\
Salicylaldehydate & 0.030 & 28 \\
Tropolonate & 0.018 & 17 \\
OCOC $_{3} \mathrm{H}_{7}-\mathrm{i}$ & 0.022 & Trace \\
\hline
\end{tabular}

* Equimolar amounts of the dimethylthallium and diethylthallium compounds were used.

change after 10 hours in refluxing benzene. However, the redistribution reactions of these compounds were found to occur gradually in refluxing toluene, and the reverse reactions also proceed at this temperature, as shown in Table 2. 


\section{R. OKAWARA}

The extreme ease of the redistribution reactions of methylethylthallium thiomethoxide and thiophenoxide and their reverse reactions may be connected with the facts that the compounds have weak $\mathrm{Tl}-\mathrm{C}$ bonds and are more or less associated in solution. On the other hand, monomeric methylethylthallium dithiocarbamate was found to be stable to the redistribution, although this compound has weak $\mathrm{Tl}-\mathrm{C}$ bonds.

\section{(ii) Alkyl replacement and dealkylation}

It was also found that tetramethyltin reacts with various unsymmetrical diorganothallium isobutylates causing a novel replacement reaction, as shown in the following equation ${ }^{23}$.

$$
\begin{gathered}
\mathrm{RR}^{\prime} \mathrm{TlY}+\left(\mathrm{CH}_{3}\right)_{4} \mathrm{Sn}+\mathrm{CH}_{3} \mathrm{OH} \rightarrow \mathrm{CH}_{3} \mathrm{RTlY}^{\prime}+\left(\mathrm{CH}_{3}\right)_{3} \mathrm{SnY}^{\prime}+\mathrm{R}^{\prime} \mathrm{H} \\
\left(\mathrm{R}=\mathrm{CH}_{3} \text { and } \mathrm{C}_{2} \mathrm{H}_{5} ; \mathrm{R}^{\prime}=\mathrm{C}_{6} \mathrm{H}_{5}, p-\mathrm{CH}_{3} \mathrm{C}_{6} \mathrm{H}_{4}, \mathrm{C}_{6} \mathrm{H}_{5} \mathrm{C} \equiv \mathrm{C}\right. \text {, and } \\
\left.\mathrm{CH}_{2}=\mathrm{CH} ; \mathrm{Y}=\mathrm{OCOC}_{3} \mathrm{H}_{7}-\mathrm{i} ; \mathrm{Y}^{\prime}=\mathrm{OCOC}_{3} \mathrm{H}_{7}-\mathrm{i} \text { and } / \text { or } \mathrm{OCH}_{3}\right)
\end{gathered}
$$

Methylethylthallium isobutylate does not undergo this reaction. In these reactions, methanol is thought to act as a proton source for the formation of the hydrocarbon $\left(R^{\prime} H\right)$, since the reactions do not proceed in methylene chloride or in chloroform. It should be noted that in these unsymmetrical diorganothallium compounds, the more electronegative group (see Table 3) is replaced. In the above reaction, the methylation by tetramethyltin and the cleavage of the $\mathrm{Tl}-\mathbf{R}^{\prime}$ bond would be expected to take place simultaneously, in the sense of a concerted mechanism, without the formation of a $\mathrm{CH}_{3} \mathrm{R} \mathrm{R}^{\prime} \mathrm{Tl}$ intermediate.

Recently we synthesized methyl(allyl)thallium carboxylates ${ }^{33}$. In the replacement reaction of these compounds, in which the allyl group is 'frozen', the less electronegative allyl group is replaced in contrast to the trend of replacement of the more electronegative group.

Similarly, in the following reactions, the allyl group in the methyl(allyl) thallium derivatives is transferred preferentially.

$$
\begin{array}{r}
\mathrm{RR}^{\prime} \mathrm{TlOCOCH} \mathrm{H}_{3}+\mathrm{Hg}\left(\mathrm{OCOCH}_{3}\right)_{2} \rightarrow \mathrm{RTl}\left(\mathrm{OCOCH}_{3}\right)_{2}+\mathrm{R}^{\prime} \mathrm{HgOCOCH}_{3} \\
\left(\mathrm{R} \text { and } \mathrm{R}^{\prime}=\mathrm{CH}_{3} \text { and } \mathrm{C}_{6} \mathrm{H}_{5} ; \mathrm{CH}_{3} \text { and } \mathrm{H}_{2} \mathrm{C}=\mathrm{CHCH}_{2} ;\right. \\
\left.\mathrm{C}_{2} \mathrm{H}_{5} \text { and } \mathrm{CH}_{3} ; \mathrm{CH}_{3} \text { and } \mathrm{CN}\right) \\
\mathrm{CH}_{3}\left(\mathrm{H}_{2} \mathrm{C}=\mathrm{CHCH}_{2}\right) \mathrm{TlOCOC} \mathrm{H}_{5}+\mathrm{Pd}\left(\mathrm{OCOC}_{2} \mathrm{H}_{5}\right)_{2} \rightarrow \\
\mathrm{CH}_{3} \mathrm{Tl}\left(\mathrm{OCOC}_{2} \mathrm{H}_{5}\right)_{2}+0.5\left(\pi-\mathrm{C}_{3} \mathrm{H}_{5} \mathrm{PdOCOC}_{2} \mathrm{H}_{5}\right)_{2}
\end{array}
$$

From these results it is likely that the cleavage of the allyl-thallium bond in these reactions is due to a specific interaction between the $\pi$-electron system and an electrophilic reagent.

\section{(iii) Miscellaneous}

The reaction products of the unsymmetrical methylorganothallium carboxylates, $\mathrm{CH}_{3} \mathrm{RTIY}$, together with those of monomethylthallium carboxylates, $\mathrm{CH}_{3} \mathrm{TlY}_{2}$ and $\mathrm{CH}_{3}(\mathrm{CN}) \mathrm{TlY}$, with some reagents such as $\mathrm{Cl}^{-}, \mathrm{B}\left(\mathrm{C}_{6} \mathrm{H}_{5}\right)_{4}^{-}$and $\mathrm{SSCN}\left(\mathrm{CH}_{3}\right)_{2}^{-}$, are summarized in Table 3. From Table 3, it is clear that the compounds $\left(\mathrm{R}=\mathrm{C}_{2} \mathrm{H}_{5}, \mathrm{H}_{2} \mathrm{C}=\mathrm{CHCH}_{2}, \mathrm{CH}_{3}\right.$, $\mathrm{CH}_{2}=\mathrm{CH}$ and $\left.\mathrm{C}_{6} \mathrm{H}_{5}\right)$ with the $J\left(\mathrm{Tl}-\mathrm{CH}_{3}\right)$ value comparable to that of the 
Table 3. $\mathrm{J}\left(\mathrm{Tl}-\mathrm{CH}_{3}\right)$ values $\left(\right.$ at $\left.20^{\circ} \mathrm{C}\right)$ for $\mathrm{CH}_{3} \mathrm{RT} 1 \mathrm{OCOR}^{\prime}$ and reaction products with $\mathrm{Cl}^{-}, \mathrm{B}\left(\mathrm{C}_{6} \mathrm{H}_{5}\right)_{4}^{-}$and $\mathrm{SSCN}\left(\mathrm{CH}_{3}\right)_{2}^{-}$

\begin{tabular}{|c|c|c|c|c|c|c|}
\hline $\mathbf{R}$ & $\mathbf{R}^{\prime}$ & Solvent & $\begin{array}{c}J\left(\mathrm{Tl}-\mathrm{CH}_{3}\right) \\
(\mathrm{Hz})\end{array}$ & $\mathrm{Cl}^{-}$ & $\mathrm{B}\left(\mathrm{C}_{6} \mathrm{H}_{5}\right)_{4}^{-}$ & $\operatorname{SSCN}\left(\mathrm{CH}_{3}\right)_{2}^{-}(=\mathrm{dtc})$ \\
\hline $\begin{array}{l}\mathrm{C}_{2} \mathrm{H}_{5} \\
\mathrm{CH}_{2}=\mathrm{CHCH}_{2} \\
\mathrm{CH}_{3} \\
\mathrm{CH}_{2}=\mathrm{CH} \\
\mathrm{C}_{6} \mathrm{H}_{5} \\
\mathrm{C}_{5} \mathrm{H}_{5} \\
\mathrm{C}_{6} \mathrm{H}_{5} \mathrm{C} \equiv \mathrm{C} \\
\mathrm{CN}\end{array}$ & $\begin{array}{l}\mathrm{C}_{3} \mathrm{H}_{7}-\mathrm{i} \\
\mathrm{C}_{3} \mathrm{H}_{7}-\mathrm{i} \\
\mathrm{C}_{3} \mathrm{H}_{7}-\mathrm{i} \\
\mathrm{C}_{3} \mathrm{H}_{7}-\mathrm{i} \\
\mathrm{C}_{3} \mathrm{H}_{7}-\mathrm{i} \\
\mathrm{C}_{3} \mathrm{H}_{7}-\mathrm{i} \\
\mathrm{CH}_{3} \\
\mathrm{CH}_{3} \\
\left(\mathrm{C}_{3} \mathrm{H}_{7}-\mathrm{i}\right)_{2}\end{array}$ & $\begin{array}{l}\mathrm{CDCl}_{3} \\
\mathrm{CDCl}_{3} \\
\mathrm{CDCl}_{3} \\
\mathrm{CDCl}_{3} \\
\mathrm{CDCl}_{3} \\
\mathrm{CDCl}_{3} \\
\mathrm{D}_{2} \mathrm{O} \\
\mathrm{D}_{2} \mathrm{O} \\
\mathrm{CHCl}_{3}\end{array}$ & $\begin{array}{l}331^{35} \\
365^{33} \\
377^{36} \\
412^{36} \\
426^{36} \\
456^{34} \\
672^{25} \\
828^{25} \\
902^{25}\end{array}$ & $\begin{array}{l}\mathrm{CH}_{3}\left(\mathrm{C}_{2} \mathrm{H}_{5}\right) \mathrm{TlCl}^{32} \\
\mathrm{CH}_{3}\left(\mathrm{CH}_{2}=\mathrm{CHCH}_{2}\right) \mathrm{TlCl}^{33} \\
\left(\mathrm{CH}_{3}\right)_{2} \mathrm{TlCl}^{36} \\
\mathrm{CH}_{3}\left(\mathrm{CH}_{2}=\mathrm{CH}\right) \mathrm{TlCl}^{23} \\
\mathrm{CH}_{3}\left(\mathrm{C}_{6} \mathrm{H}_{5}\right) \mathrm{TlCl}^{32} \\
\mathrm{TlCl}^{34} \\
\mathrm{CH}_{3}\left(\mathrm{C}_{6} \mathrm{H}_{5} \mathrm{C} \equiv \mathrm{C}\right) \mathrm{TlCl}^{25} \\
\mathrm{TlCl}^{36} \\
\mathrm{TlCl}^{22}\end{array}$ & $\begin{array}{l}\mathrm{CH}_{3}\left(\mathrm{C}_{2} \mathrm{H}_{5}\right) \mathrm{TlB}\left(\mathrm{C}_{6} \mathrm{H}_{5}\right)_{4} \\
\mathrm{CH}_{3}\left(\mathrm{CH}_{2}=\mathrm{CHCH} \mathrm{CH}_{2}\right) \mathrm{TlB}\left(\mathrm{C}_{6} \mathrm{H}_{5}\right)_{4} \\
\left(\mathrm{CH}_{3}\right)_{2} \mathrm{TlB}\left(\mathrm{C}_{6} \mathrm{H}_{5}\right)_{4} \\
\mathrm{CH}_{3}\left(\mathrm{CH}_{2}=\mathrm{CH}\right) \mathrm{TlB}_{2}\left(\mathrm{C}_{6} \mathrm{H}_{5}\right)_{4} \\
\mathrm{CH}_{3}\left(\mathrm{C}_{6} \mathrm{H}_{5}\right) \mathrm{TlB}\left(\mathrm{C}_{6} \mathrm{H}_{5}\right)_{4}{ }^{25} \\
\mathrm{CH}_{3}\left(\mathrm{C}_{6} \mathrm{H}_{5}\right) \mathrm{TlB}\left(\mathrm{C}_{6} \mathrm{H}_{5}\right)_{4}{ }^{34} \\
\mathrm{CH}_{3}\left(\mathrm{C}_{6} \mathrm{H}_{5} \mathrm{C} \equiv \mathrm{C}\right) \mathrm{ClB}\left(\mathrm{C}_{6} \mathrm{H}_{5}\right)_{4}{ }^{25} \\
\mathrm{CH}_{3}\left(\mathrm{C}_{6} \mathrm{H}_{5}\right) \mathrm{TlB}\left(\mathrm{C}_{6} \mathrm{H}_{5}\right)_{4}{ }^{25} \\
\mathrm{CH}_{3}\left(\mathrm{C}_{6} \mathrm{H}_{5}\right) \mathrm{TlB}\left(\mathrm{C}_{6} \mathrm{H}_{5}\right)_{4}{ }^{25}\end{array}$ & $\begin{array}{l}\mathrm{CH}_{3}\left(\mathrm{C}_{2} \mathrm{H}_{5}\right) \mathrm{Tl}\left(\mathrm{dtc}^{35}\right. \\
\mathrm{CH}_{3}\left(\mathrm{CH}_{2}=\mathrm{CHCH}{ }_{2}\right) \mathrm{Tl}(\mathrm{dtc})^{33} \\
\left(\mathrm{CH}_{3}\right)_{2} \mathrm{Tl}(\mathrm{dtc}) \\
\mathrm{CH}_{3}\left(\mathrm{CH}_{2}=\mathrm{CH}\right) \mathrm{Tl}(\mathrm{dtc}) \\
\mathrm{CH}_{3}\left(\mathrm{C}_{6} \mathrm{H}_{5}\right) \mathrm{Tl}(\mathrm{dtc}) \\
\mathrm{CH}_{3} \mathrm{Tl}(\mathrm{dtc})_{2}{ }^{34} \\
\mathrm{CH}_{3} \mathrm{Tl}(\mathrm{dtc})_{2}{ }^{36} \\
\mathrm{CH}_{3} \mathrm{Tl}(\mathrm{dtc})_{2}{ }^{26} \\
\mathrm{CH}_{3} \mathrm{Tl}(\mathrm{dtc})_{2}{ }^{29}\end{array}$ \\
\hline
\end{tabular}




\section{R. OKAWARA}

dimethylthallium compound gave the reaction products maintaining the $\mathrm{CH}_{3}-\mathrm{T} 1-\mathrm{R}$ moiety. As far as the reaction products are concerned, the cyclopentadienyl compound behaves just like the monomethyl compound, in spite of the fact that its $J$ value (456) is close to that of the phenyl compound (426). This may be associated with the fluxional behavior of the cyclopentadienyl group bonded to the thallium atom, as indicated from the spectroscopic data ${ }^{34}$.

\section{COORDINATION CHEMISTRY OF MONOALKYLTHALLIUM COMPOUNDS}

From the i.r. and u.v. spectra, it was deduced that the monomeric monoalkylthallium chelate compounds, such as bisoxinate, bistropolonate or bisdithiocarbamate have a penta-coordinate thallium atom, similar to the reported monophenylthallium compounds, $\mathrm{C}_{6} \mathrm{H}_{5} \mathrm{Tl}$ (oxinate) ${ }_{2}{ }^{37}$ and $\left[\mathrm{C}_{6} \mathrm{H}_{5} \mathrm{TlCl}_{4}\right]^{2-38,39}$. The penta-coordinate thallium was also suggested to exist in $\mathrm{RTl}\left(\mathrm{OCOC}_{3} \mathrm{H}_{7}-\mathrm{i}\right)_{2}\left(\mathrm{R}=\mathrm{CH}_{3}\right.$ or $\left.\mathrm{C}_{2} \mathrm{H}_{5}\right)$ in non-polar solvents, from the molecular weight and i.r. measurements ${ }^{22}$. The results of the farinfrared spectra of $\mathrm{RTl}(\mathrm{Y}) \mathrm{OAc}\left(\mathrm{R}=\mathrm{CH}_{3}\right.$ or $\mathrm{C}_{6} \mathrm{H}_{5} ; \mathrm{Y}=\mathrm{OAc}$ or $\left.\mathrm{CN}\right)$ in the solid state showed that in these compounds the alkyl group and one ligand $(\mathrm{Y})$ interact strongly with the thallium atom ${ }^{27}$, as in RHgY. This conclusion is also supported by the similar study of monophenylthallium dicarboxylates ${ }^{40}$.
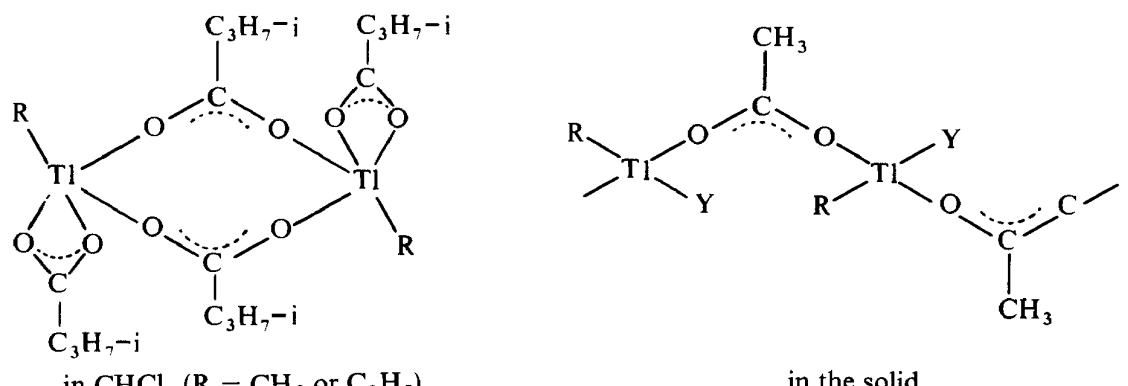

in $\mathrm{CHCl}_{3}\left(\mathrm{R}=\mathrm{CH}_{3}\right.$ or $\left.\mathrm{C}_{2} \mathrm{H}_{5}\right)$

in the solid

$$
\begin{aligned}
(\mathrm{R} & =\mathrm{CH}_{3} \text { or } \mathrm{C}_{6} \mathrm{H}_{5}: \\
\mathrm{Y} & =\mathrm{OAc} \text { or } \mathrm{CN})
\end{aligned}
$$

Table 4. $J\left(\mathrm{Tl}-\mathrm{CH}_{3}\right), \rho\left(\mathrm{T} 1-\mathrm{CH}_{3}\right)$ and $v\left(\mathrm{~T} 1-\mathrm{CH}_{3}\right)$ for some $\mathrm{CH}_{3} \mathrm{TlX}{ }_{2}$

\begin{tabular}{lccl}
\hline \multicolumn{1}{c}{$\mathrm{X}$} & $\begin{array}{c}J\left(\mathrm{~T} 1-\mathrm{CH}_{3}\right)^{*} \\
(\mathrm{~Hz})\end{array}$ & $\begin{array}{c}\rho\left(\mathrm{Tl}-\mathrm{CH}_{3}\right) \dagger \\
\left(\mathrm{cm}^{-1}\right)\end{array}$ & $\begin{array}{c}v\left(\mathrm{Tl}-\mathrm{CH}_{3}\right) \dagger \\
\left(\mathrm{cm}^{-1}\right)\end{array}$ \\
\hline OCOC $_{3} \mathrm{H}_{7}-\mathrm{i}$ & 902 & $813(\mathrm{~s})$ & $\vdots$ \\
OCOCH $_{3}$ & 892 & $810(\mathrm{~s})$ & $527(\mathrm{~m})$ \\
tropolonate & 835 & $806(\mathrm{~s})$ & $510(\mathrm{~m})$ \\
oxinate & 790 & $\ddagger$ & $514(\mathrm{~m})$ \\
SSCN $\left(\mathrm{CH}_{3}\right)_{2}$ & 678 & $781(\mathrm{~s})$ & $487(\mathrm{~m})$ \\
SSCN $\left(\mathrm{C}_{2} \mathrm{H}_{5}\right)_{2}$ & 675 & $778(\mathrm{~s})$ & $485(\mathrm{~m})$ \\
\hline
\end{tabular}

\footnotetext{
* In $\mathrm{CDCl}_{3}$ solutions ( $5 \mathrm{wt} \%$ ).

$\leftarrow$ In Nujol mulls.

$\ddagger$ Obscured by the strong absorptions due to the ligand
} 
From the spectral parameters for several monoalkylthallium derivatives (Table 4) it was found that the thallium atom interacts more strongly with the sulphur atom than the oxygen and/or nitrogen atoms ${ }^{29}$.

\section{ACKNOWLEDGEMENT}

The author wishes to thank his students, Dr. K. Yasuda (1967), Dr. H. Kurosawa (1970), Mr. M. Tanaka (1969), Mr. T. Abe, Mr. T. Fukumoto and $\mathrm{Mr}$. K. Tanaka for their contributions to this work.

\section{REFERENCES}

1 H. Kurosawa and R. Okawara. Organomet. Chem. Rev. (A). 6. 65 (1970).

2 A. G. Lee. Quart. Rev. 24, 310 (1970).

3 K. Yasuda and R. Okawara, Organomet. Chem. Rev. 2, 255 (1967).

4 F. Challenger and B. Parker, J. Chem. Soc. 1462 (1931).

5 F. Challenger and O. V. Richards. J. Chem. Soc. 405 (1934).

${ }^{6}$ N. S. Nametkin. N. N. Melinikov and G. P. Gracheva, J. Gen. Chem. USSR, 5, 1455 (1935); Chem. Abstr. 30. 2182 (1936).

7 A. N. Nesmeyanov. A. E. Borisov and M. A. Osipova. Dokl. Akad. Nauk USSR. 169. 602 (1966): Chem. Abstr. 65, 15411a (1966).

${ }^{8}$ D. Goddard and A. E. Goddard. J. Chem. Soc. 256 (1922).

9 A. E. Borisov and M. A. Osipova. Izvest. Akad. Nauk USSR. Otdel. Khim. Nauk. 1039 (1961): Chem. Abstr. 55. 27171c (1961).

10 V. P. Glushkova and K. A. Kocheskov, Dokl. Akad. Nauk USSR. 103. 615 (1955): Chem. Abstr. 50. 5619d (1956).

11 V. P. Glushkova and K. A. Kocheskov. Dokl. Akad. Nauk USSR. 116. 233 (1957): Chem. Abstr. 52, 6236i (1958).

12 V. P. Glushkova and K. A. Kocheskov, Izvest. Akad. Nauk USSR, Otdel. Khim. Nauk. 1193 (1957): Chem. Abstr. 52, 6239d (1958).

13 H. J. Kabbe. Ann. Chem. 656, 204 (1962).

14 A. E. Borisov and N. V. Novikova, Izvest. Akad. Nauk USSR. Otdel. Khim. Nauk. 1670 (1959): Chem. Abstr. 54. 8608i (1960).

15 N. N. Melnikov and G. P. Gratscheva, J. Gen. Chem. USSR. 5. 1786 (1935): Chem. Abstr. 30. 3403 (1936).

16 V. D. Sarrach, Z. Anorg. Allgem. Chem. 319, 16 (1962).

17 C. R. Hart and C. K. Ingold. J. Chem. Soc. 4372 (1964).

18 H. Kurosawa and R. Okawara. Inorg. Nucl. Chem. Letters. 3. 21 (1967).

19 J. V. Hatton, J. Chem. Phys. 40, 933 (1964).

20 J. P. Maher and D. F. Evans, J. Chem. Soc. 637 (1965).

21 H. Kurosawa and R. Okawara, Inorg. Nucl. Chem. Letters. 3.93 (1967).

22 H. Kurosawa and R. Okawara, J. Organomet. Chem. 10. 211 (1967).

23 M. Tanaka, H. Kurosawa and R. Okawara, J. Organomet. Chem. 18. 49 (1969).

${ }^{24} \mathrm{H}$. Kurosawa and R. Okawara, unpublished results.

25 H. Kurosawa. M. Tanaka and R. Okawara, J. Organomet. Chem. 12. 241 (1968).

26 T. Fukumoto, H. Kurosawa and R. Okawara, J. Organomet Chem. 22, 627 (1970).

27 H. Kurosawa and R. Okawara, J. Organomet. Chem. 19, 253 (1969).

28 H. Kurosawa, T. Fukumoto and R. Okawara. Inorg. Nucl. Chem. Letters. 5. 473 (1969).

29 H. Kurosawa and R. Okawara. J. Organomet. Chem. 14. 22.5 (1968).

30 K. Tanaka, H. Kurosawa and R. Okawara, J. Organomet. Chem., 30, 1 (1971).

31 J. R. Cook and D. F. Martin, J. Inorg. Nucl. Chem. 26. 1249 (1964).

32 M. Tanaka, H. Kurosawa and R. Okawara; Inorg. Nucl. Chem. Letters. 3. 565 (1967).

${ }^{33}$ T. Abe. H. Kurosawa and R. Okawara, J. Organomet. Chem. 25. 353 (1970).

${ }^{34}$ T. Abe and R. Okawara, J. Organomet. Chem. in press.

${ }^{35}$ M. Tanaka, H. Kurosawa and R. Okawara. J. Organomet. Chem. 21. 41 (1970). 


\section{R. OKAWARA}

${ }^{36}$ R. Okawara et al. unpublished data.

37 G. Faraglia, L. Roncucci and R. Barbieri, Ric. Sci. Rend. 8A, 205 (1965).

38 G. Faraglia, L. Roncucci Fiorani, B. L. Pepe and R. Barbieri, Inorg. Nucl. Chem. Letters, 2, 277 (1966).

39 G. Faraglia, L. Roncucci Fiorani, B. L. Pepe and R. Barbieri, J. Organomet. Chem. 10, 363 (1967).

40 A. G. Lee, J. Organomet. Chem. 22, 537 (1970). 